\title{
Genetic polymorphism of histone H1.z in duck erythrocytes
}

\author{
Jan PALYGA, Ewa GÓRNICKA-MICHALSKA and Andrzej KOWALSKI \\ Department of Genetics, Educational University of Kielce, 25-518 Kielce, Warszawska 33, Poland
}

Three different phenotypes of erythrocyte histone H1.z were detected in several lines of duck by using two-dimensional PAGE. Electrophoresis and inheritance data have shown that two co-dominant alleles, $z^{1}$ and $z^{2}$, encode two proteins which differ slightly in their apparent molecular masses. Allele $z^{1}$ was very abundant and was found at a frequency at least 0.94 , while allele $z^{2}$ was very rare and was present at a frequency of less than 0.06. Limited chemical and enzymic cleavages appeared to indicate that the allelic forms of histone H1.z differed in the Cterminal regions of their molecules.

\section{INTRODUCTION}

A family of histone $\mathrm{H} 1$ proteins in avian cells contains at least six components (Shannon and Wells, 1987; Pałyga, 1991c) that interact with nucleosome particles formed by an octamer of core histones (H2A, H2B, H3 and H4) around which is wound approximately two turns of DNA. Histone $\mathrm{H} 1$ binds to the nucleosome with a conservative central domain at the entry and exit points of the DNA, while the more variable positively charged $\mathrm{N}$ - and $\mathrm{C}$-terminal tails of the molecule interact with the linker DNA (Thomas, 1984). Apart from its structural function (Roth and Allis, 1992), histone H1 also participates in repression of the genome (Croston et al., 1991). The histone H1-mediated repression, unlike the repression by nucleosome cores located at the RNA start sites (Laybourn and Kadonaga, 1991), can be counteracted in vitro by the addition of some sequence-specific transcription factors. The interaction of lysine-rich histones $(\mathrm{H} 1$ and H5) with chromatin seems to be correlated both with their amino acid composition, especially with a large arginine content (Kostyleva et al., 1989), and with a capability of adopting a conserved structure during binding to DNA (Maeder and Böhm, 1991).

In addition to a standard set of non-allelic $\mathrm{H} 1$ histones in avian erythrocytes, we have detected allelic variants of $\mathrm{H} 1$ subtypes in the goose (Pałyga, 1990a), quail (Pałyga, 1991a) and duck (Pałyga, 1991b). Since the allelic forms of an H1 subtype can be distributed differently in genetically distinct races of animals (Pałyga, 1990a,b, 1991b), it seems that a particular allelic form of histone $\mathrm{Hl}$ might contribute to the structure or function of chromatin.

The present work is aimed at the detection and characterization of polymorphism of H1.z, a newly distinguished variant of histone $\mathrm{H} 1$ in duck erythrocytes (Pałyga, 1991b).

\section{MATERIALS AND METHODS}

\section{Animals}

Five lines of duck (A4, A5, K01, P6 and P7) were bred at the Poultry Research and Development Center, Branch of Waterfowl Breeding in Dworzyska, Poznań, Poland. Blood was collected from the wing veins into a cooled solution containing $0.15 \mathrm{M}$ $\mathrm{NaCl}, 0.015 \mathrm{M}$ sodium citrate and $0.1 \mathrm{mM} \mathrm{CdSO}_{4}$.

\section{Extraction of erythrocyte proteins soluble in $0.5 \mathrm{M} \mathrm{HCIO}$,}

Blood cells were pelleted by centrifugation, and the supernatant along with a layer of leucocytes was removed by aspiration. The pellet containing red blood cells was washed twice more with $0.15 \mathrm{M} \mathrm{NaCl}$ and $0.015 \mathrm{M}$ sodium citrate supplemented with $0.1 \mathrm{mM} \mathrm{CdSO}_{4}$ and $0.5 \mathrm{mM}$ phenylmethanesulphonyl fluoride. The washed erythrocytes were stored at $-20^{\circ} \mathrm{C}$ until used.

Proteins soluble in dilute perchloric acid solution were isolated from whole erythrocytes (Pałyga, 1991b). Briefly, the erythrocyte pellet was thawed at $0-4{ }^{\circ} \mathrm{C}$, suspended in $0.5 \mathrm{M} \mathrm{HClO}_{4}$ using a Teflon/glass homogenizer and centrifuged. Trichloroacetic acid was added to the supernatant to a final concentration of $20 \%$, and the precipitate was washed with acidified acetone, then with acetone, and finally air-dried.

\section{PAGE analysis}

Protein samples were analysed in a two-dimensional polyacrylamide slab gel (Pałyga, 1991b). Protein was first resolved in an acid/urea gel containing $15 \%$ acrylamide, $0.5 \% N N^{\prime}$ methylenebisacrylamide, $8 \mathrm{M}$ urea and $0.9 \mathrm{M}$ acetic acid (Berdnikov and Gorel, 1975). After staining with Coomassie Blue, gel strips containing histone $\mathrm{H} 1 . \mathrm{z}$ were cut out and incubated in an adaptation buffer $(0.1 \%$ SDS, $10 \%$ glycerol, $0.125 \mathrm{M}$ Tris/ $\mathrm{HCl}, \mathrm{pH} 6.8$, and $1 \mathrm{mM}$ EDTA). The gel pieces were placed on top of a previously polymerized polyacrylamide slab gel containing $13.5 \%$ acrylamide, $0.36 \% N N^{\prime}-$ methylenebisacrylamide and $0.1 \%$ SDS (Laemmli, 1970).

\section{Cleavage of H1.z with $\boldsymbol{N}$-bromosuccinimide (NBS)}

The stained strips of the acid/urea gel containing phenotypically different fractions of $\mathrm{H} 1 . \mathrm{z}(\mathrm{z} 1, \mathrm{z} 1 \mathrm{z} 2$ and $\mathrm{z} 2)$ were incubated in the dark for $6 \mathrm{~h}$ with $0.5 \mathrm{ml}$ of freshly prepared $0.1 \% \mathrm{NBS}$ in $50 \%$ acetic acid. After $3 \mathrm{~h}$ of incubation another $0.25 \mathrm{ml}$ aliquot of NBS solution was added, and finally the incubation was stopped by adding $1.5 \mathrm{mg}$ of tyrosine dissolved in $50 \%$ acetic acid. The gel pieces containing cleaved H1.z were placed directly on top of a $15 \%$ polyacrylamide slab gel containing acetic acid and urea. For SDS/PAGE, the strips of acid/urea gel, after the reaction had been stopped with tyrosine, were 'adapted' for $3 \times 15 \mathrm{~min}$ in the adaptation buffer (see above) and placed on top of a polymerized $15 \%$ polyacrylamide gel containing $0.1 \%$ SDS (Laemmli, 1970). Carbonic anhydrase (molecular mass $29 \mathrm{kDa}$ ), soybean trypsin inhibitor $(21 \mathrm{kDa})$, myoglobin $(17.8 \mathrm{kDa})$ and cytochrome $c(12.5 \mathrm{kDa})$ were used as molecular mass standards. 


\section{Limited proteolysis of H1.z with $\alpha$-chymotrypsin}

The stained fragments of the acid/urea gel containing homozygotic (z1 or z2) or heterozygotic (z1z2) forms of H1.z were first incubated for $3 \times 15 \mathrm{~min}$ in the adaptation buffer, and then immersed in $0.3 \mathrm{ml}$ of the adaptation buffer containing $200 \mu \mathrm{g}$ of $\alpha$-chymotrypsin (Sigma) and incubated for $30 \mathrm{~min}$ at room temperature. The time of incubation and the amount of $\alpha$ chymotrypsin were determined in trial experiments. After a 30 min incubation, the reaction solutions with gel strips were heated in a boiling water bath for $2 \mathrm{~min}$ to inactivate the enzyme. The gel pieces were placed on top of a $15 \%$ polyacrylamide gel containing $0.1 \%$ SDS (Laemmli, 1970). After completion of the electrophoretic run, the gel was stained with silver (Sambrook et al., 1989).

\section{Direct digestion of H1.z in the SDS/polyacrylamide gel with protease V8 from Staphylococcus aureus}

Acetic acid/urea gel fragments containing proteins $\mathrm{z} 1, \mathrm{z} 1 \mathrm{z} 2$ or $\mathrm{z} 2$ were soaked in the SDS adaptation buffer. The gel samples were loaded into the wells of a $15 \%$ polyacrylamide gel containing SDS (Cleveland et al., 1977), and each piece of the gel was overlayered with $4 \mu \mathrm{l}$ of solution containing protease $\mathrm{V} 8$ dissolved in the adaptation buffer at a concentration of $1 \mu \mathrm{g} / \mu \mathrm{l}$. When the Bromophenol Blue reached the bottom of the stacking gel the current was turned off for $30 \mathrm{~min}$, after which the electrophoresis was resumed.

\section{Digestion of NBS-cleaved H1.z with protease V8}

Three phenotypic forms of H1.z were cut out of the acid/urea gel and treated with NBS as described above. After incubation in the adaptation buffer for SDS gels, the gel fragments containing the appropriate proteins were inserted into the wells of an SDS/polyacrylamide gel and overlayered with incubation buffer containing protease $\mathrm{V} 8$.

\section{RESULTS AND DISCUSSION}

\section{Variability of histone H1.z in duck populations}

Perchloric acid-soluble proteins from erythrocytes of individual ducks were compared using both SDS/ (Figure la) and acid/urea/ (Figure 1b) polyacrylamide gels. In the acid/urea gel a standard pattern of duck $\mathrm{H} 1$ proteins was obtained, including an $\mathrm{H} 1.2$ histone that migrated as a single band in preparations from all animals tested. In the SDS gel patterns, however, three phenotypes of H1.z were distinguished among individuals of a duck population: a homozygous phenotype zl giving variant H1.zl, which migrated more slowly than subtype H1.a (which is equivalent to $\mathrm{H} 1.2$ ), a homozygous phenotype $\mathrm{z} 2$ giving variant H1.z2, which migrated just ahead of histone H1.a, and a heterozygotic phenotype $\mathrm{zlz2}$ containing both proteins in approximately equal amounts. The results obtained by onedimensional SDS/PAGE were confirmed by resolving the histone $\mathrm{H} 1$ preparations from individual birds in a two-dimensional polyacrylamide gel (Figure 1c). The distribution of the phenotypes and alleles of H1.z in five genetic lines of ducks is presented in Table 1. Most animals contained slowly moving protein zl (allele $z^{1}$ ). The homozygous birds with allele $z^{2}$ were very rare in our duck populations. The animals that were heterozygous at this locus constituted about $3.5-6 \%$ of the A4, A5 and K01 lines, were approx. 2-3 times more abundant in the P7 line, and were undetectable in the P6 line. Recently we have shown (Pałyga, 1991a) that quail H1.z is an erythrocyte-specific subtype, since it is absent from liver $\mathrm{H} 1$ histones, resembling in this respect chicken H1.a' (Shannon and Wells, 1987), which is present only in erythrocytes (Berdnikov et al., 1976). It is possible that subtype H1.z, the migration of which varies greatly in various avian species (Pałyga, 1991c), might be a counterpart of chicken H1.a', but additional work is needed to confirm this.

The pattern of inheritance of histone H1.z is shown in Table 2. Although the number of homozygous or heterozygous birds containing allele $z^{2}$ was limited, the available mating data demonstrated that phenotypic variants of $\mathrm{H} 1 . \mathrm{z}$ were coded by a gene with two co-dominant alleles at a locus. Thus differences in the electrophoretic mobility of $\mathrm{H1.z}$ from various individuals on SDS/PAGE might reflect changes in the structure of the protein. A possible post-translational modification of erythrocyte $\mathrm{H} 1 . \mathrm{z}$
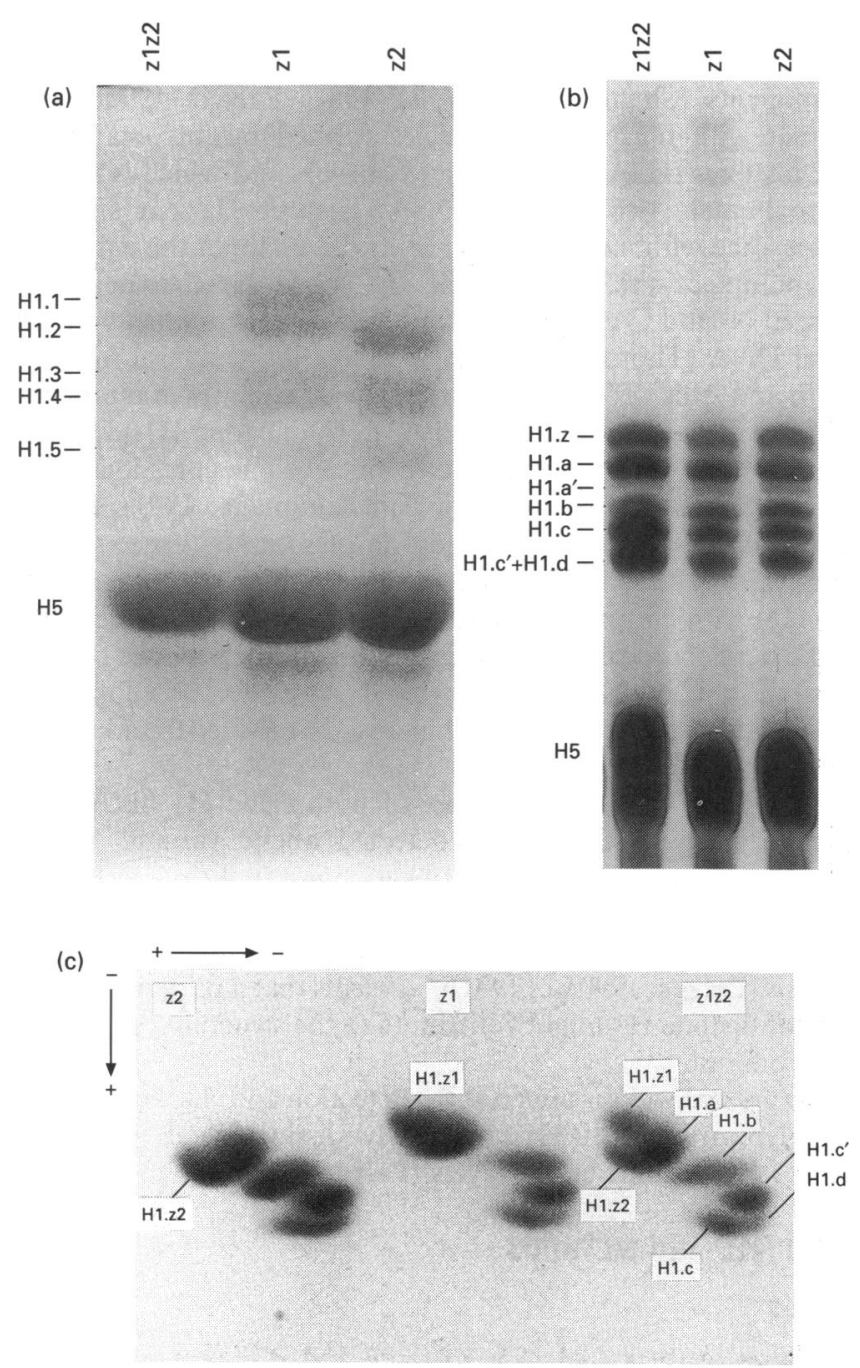

Figure 1 Phenotypes of histone H1.z from duck erythrocytes in a $13.5 \%$ polyacrylamide gel containing $0.1 \%$ SDS (a), a $15 \%$ polyacrylamide gel containing acetic acld and urea (b), and a two-dimensional polyacrylamide gel (c)

$\mathrm{H} 5$, histone $\mathrm{H} 5 ; \mathrm{H} 1 . \mathrm{a}-\mathrm{H} 1.2$, histone $\mathrm{H} 1$ subtypes in the acid/urea gel; $\mathrm{H} 1.1-\mathrm{H} 1.5$, subtypes of $\mathrm{H} 1$ in the SDS gel. In the one-dimensional SDS gel (a), histone H1.2 migrated as H1.1 (phenotype 21) or just ahead of $\mathrm{H} 1.2$ (phenotype z2). In heterozygotes both allelic forms of $\mathrm{H} 1 . \mathrm{z}$ were present; the $\mathrm{H} 1.2$ band is about twice as heavily stained as $\mathrm{H} 1.1$ due to a close migration of H1.a and H1.z2. 
Table 1 Frequency of phenotypes and alleles of erythrocyte H1.2 in various duck lines

\begin{tabular}{|c|c|c|c|c|c|c|c|c|c|}
\hline \multirow[b]{2}{*}{ Line } & \multirow{2}{*}{$\begin{array}{l}\text { Total number } \\
\text { of birds }\end{array}$} & \multicolumn{3}{|c|}{$\begin{array}{l}\text { Number of individuals } \\
\text { with phenotype }\end{array}$} & \multicolumn{3}{|c|}{$\begin{array}{l}\text { Frequency of } \\
\text { phenotypes }\end{array}$} & \multicolumn{2}{|c|}{$\begin{array}{l}\text { Frequency of } \\
\text { alleles }\end{array}$} \\
\hline & & 21 & $z 1 z 2$ & $\mathrm{Z2}$ & 21 & $21 z 2$ & $z 2$ & $z^{1}$ & $z^{2}$ \\
\hline P7 & 365 & 320 & 44 & 1 & 0.877 & 0.120 & 0.003 & 0.94 & 0.06 \\
\hline A5 & 164 & 154 & 10 & 0 & 0.939 & 0.061 & 0 & 0.97 & 0.03 \\
\hline K01 & 481 & 458 & 22 & 1 & 0.952 & 0.046 & 0.002 & 0.98 & 0.02 \\
\hline A4 & 28 & 27 & 1 & 0 & 0.964 & 0.036 & 0 & 0.98 & 0.02 \\
\hline P6 & 29 & 29 & 0 & 0 & 1.000 & 0 & 0 & 1 & 0 \\
\hline
\end{tabular}

Table 2 Distribution of phenotypes of erythrocyte histone H1.z in progeny from various duck matings

The mating data indicate that histone $\mathrm{H} 1 . \mathrm{z}$ is coded by a gene with two co-dominant alleles at a locus

\begin{tabular}{|c|c|c|c|c|c|c|}
\hline \multirow{2}{*}{$\begin{array}{l}\text { Type of mating } \\
\left(\sigma^{*} \times q\right)\end{array}$} & \multicolumn{2}{|c|}{ Numbers of } & \multicolumn{4}{|c|}{$\begin{array}{l}\text { Distribution of phenotypes in progeny } \\
\text { (observed/expected) }\end{array}$} \\
\hline & Families & Progeny & 21 & $z 1 z 2$ & Z2 & $\chi^{2}$ \\
\hline$z 1 \times z 1$ & 94 & 319 & $319 / 319$ & & & 0 \\
\hline $21 z 2 \times z 1$ & 2 & 31 & $20 / 15.5$ & $11 / 15.5$ & & 2.61 \\
\hline$z 1 \times z 1 z 2$ & 13 & 38 & $25 / 19$ & $13 / 19$ & & 3.79 \\
\hline$z 1 z 2 \times z 1 z 2$ & 3 & 5 & $2 / 1.25$ & $3 / 2.5$ & $0 / 1.25$ & - \\
\hline$z 1 \times z 2$ & 1 & 1 & & $1 / 1$ & & - \\
\hline
\end{tabular}

molecules did not seem to contribute significantly to the observed intrapopulation variability of H1.z, since the level of phosphorylated $\mathrm{H} 1$ histones in the cells with condensed chromatin such as mature erythrocytes was very low (Roth and Allis, 1992). Selective proteolysis of nucleosomal histones during irreversible silencing of Tetrahymena macronuclei was postulated (Lin et al., 1991) to participate in the formation of highly condensed chromatin, but this process was not accompanied by degradation of $\mathrm{H} 1$ histone. It seems that allelic forms of $\mathrm{H} 1 . \mathrm{z}$ from duck erythrocytes are not the products of this type of selective proteolysis, however, because the relative contents of the $\mathrm{z} 1$ and $\mathrm{z} 2$ proteins in the heterozygotic birds were similar. It is well known that one-subunit co-dominant allelic proteins are present in equivalent amounts in heterozygotes (Harris, 1980). Moreover, we have found (Pałyga, 1990b, 1991a) that the same allelic form of the polymorphic subtype of $\mathrm{H} 1$ was present in all tissues of any individual studied.

\section{Chemical and enzymic cleavage of allelic forms of H1.z}

To identify the region of the H1.z molecule that is responsible for differences between allelic forms (i.e. $z 1$ or z2), the Coomassie Blue-stained bands of $\mathrm{H} 1 . \mathrm{z}$ from different phenotypes (z1, z2 and z1z2) were cut out of the acid/urea gel and treated with various agents (NBS, $\alpha$-chymotrypsin or protease V8 from Staphylococcus aureus) that specifically cleave polypeptide bonds. The products of the chemical and enzymic degradations of the tested proteins were electrophoresed in a polyacrylamide gel. It was found that the SDS/polyacrylamide gel, which separates proteins mainly according to their molecular masses, was particularly suitable for this purpose.

The polypeptides resulting from the cleavage of polymorphic forms of $\mathrm{H} 1 . \mathrm{z}$ with NBS migrated in an acid/urea gel as a single protein band (designated ' $C$ ' in Figure 2a), resembling in this respect the pattern of migration of uncleaved H1.z proteins
(Figure 1b) which migrated with similar mobilities regardless of the phenotype of their origin. At room temperature and at pH 3-4, NBS cleaves polypeptide bonds created by carboxy moieties of tyrosine or tryptophan (Ramachandran and Witkop, 1967). Since H1 histones do not contain tryptophan (Bustin and Cole, 1969), the NBS must act specifically on the tyrosyl-peptide bond of H1.z. Histone $\mathrm{H} 1$ from duck contains a single $\mathrm{Tyr}$ residue at position 71 (Tönjes and Doenecke, 1987), but the primary structure of the duck H1.z subtype is not known. Since H1 variants exhibit a remarkable similarity in their amino acid sequences within an avian species (Shannon and Wells, 1987), here we have assumed that the Tyr residue in duck histone H1.z is placed at or very close to position 71. Thus duck histone H1.Z should be cleaved by NBS into two peptides: an N-peptide (from the $\mathrm{N}$-terminus of $\mathrm{H} 1$ to $\mathrm{Tyr}^{71}$ ) and a C-peptide (from residue 72 to the $\mathrm{C}$-terminus of $\mathrm{H} 1$ ). As the $\mathrm{N}$-terminal peptide stained inefficiently due to its small molecular mass, only the $\mathrm{C}$-terminal peptide could be detected in the polyacrylamide gel (Figure $2 \mathrm{a}$; see also Gorel et al., 1982; Hoyer-Fender and Grossbach, 1988). Although the electrophoretic mobilities of the C-terminal peptides from the two allelic subtypes of $\mathrm{H} 1 . \mathrm{z}$ were similar in an acid/urea gel (Figure 2a), distinct differences in migration in an SDS gel were found between the C-terminal peptides, designated here as $\mathrm{C}_{1}$ and $\mathrm{C}_{2}$, which were obtained from H1.z1 and H1.z2 proteins respectively following treatment with NBS (Figure $2 b$ ). The $C_{1}$ and $C_{2}$ peptides ciffered in their apparent molecular masses by about $1 \mathrm{kDa}$. The results of this comparison clearly indicate that putative differences in the amino acid sequences of H1.zl and H1.z2 are located in the region between amino acid residue 72 and the $\mathrm{C}$-terminus.

Another cleavage agent used for investigating the structure of $\mathrm{H} 1$ histones is $\alpha$-chymotrypsin (Bradbury et al., 1975), which in $\mathrm{H} 1$ cleaves in the first instance peptide bonds containing the carboxy group of the phenylalanine. Duck erythrocyte histone $\mathrm{H} 1$ contains only a single $\mathrm{Phe}$ residue, at position 105 (Tönjes and 


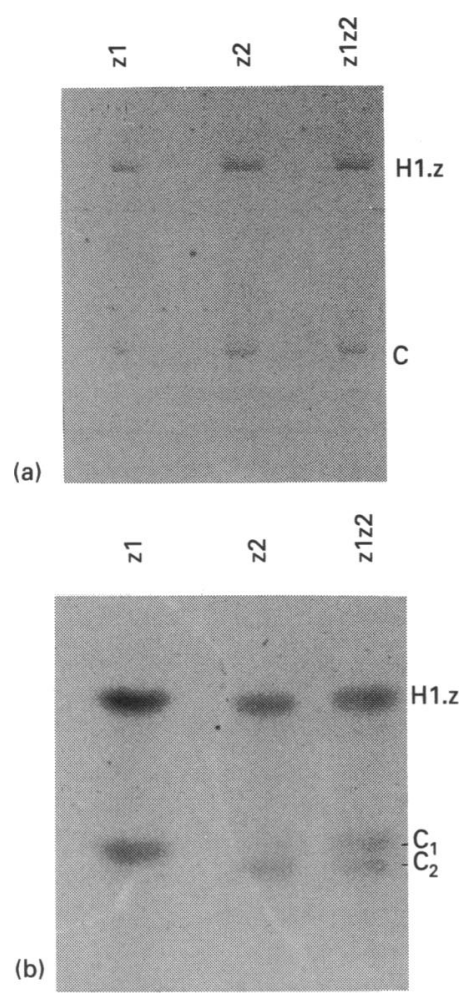

Figure 2 Partial cleavage by NBS at a single tyrosine residue of histone H1.z from homozygous (21 or 22) and heterozygous (2122) ducks

Products of cleavage were resolved in an acetic acid/urea gel (a) or in a $15 \%$ polyacrylamide gel containing SDS (b). C, a C-terminal fragment of $\mathrm{H} 1.2$ resolved in the acid/urea gel after treatment with NBS; $\mathrm{C}_{1}$ and $\mathrm{C}_{2}, \mathrm{C}$-terminal fragments of $\mathrm{H} 1.21$ and $\mathrm{H} 1.22$, respectively after NBS treatment. The apparent molecular masses of peptides $C_{1}$ and $C_{2}$ differed by approx. $1 \mathrm{kDa}$.

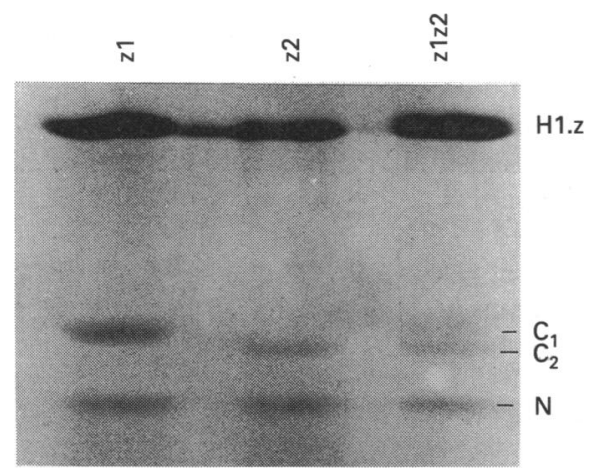

Figure 3 Limited degradation with $\alpha$-chymotrypsin of erythrocyte H1.z subtypes from homozygous and heterozygous ducks

Digestion products were resolved in a $15 \%$ polyacrylamide gel containing SDS. The gel was stained with silver (Sambrook et al., 1989). $C_{1}$, chymotryptic C-terminal peptide from the H1.z1 subfraction; $\mathrm{C}_{2}$, chymotryptic C-terminal peptide from the $\mathrm{H} 1.22$ subfraction; N, chymotryptic $\mathrm{N}$-terminal peptide from $\mathrm{H} 1.21$ and/or $\mathrm{H} 1.22$.

Doenecke, 1987). Cleavage of H1.z with $\alpha$-chymotrypsin should thus produce two peptides: an $\mathrm{N}$-terminal peptide, from the $\mathrm{N}$ terminus to $\mathrm{Phe}^{105}$, and a longer C-terminal peptide (Figure 3). It appeared that treating $\mathrm{H} 1 . \mathrm{zl}$ with $\alpha$-chymotrypsin led to a

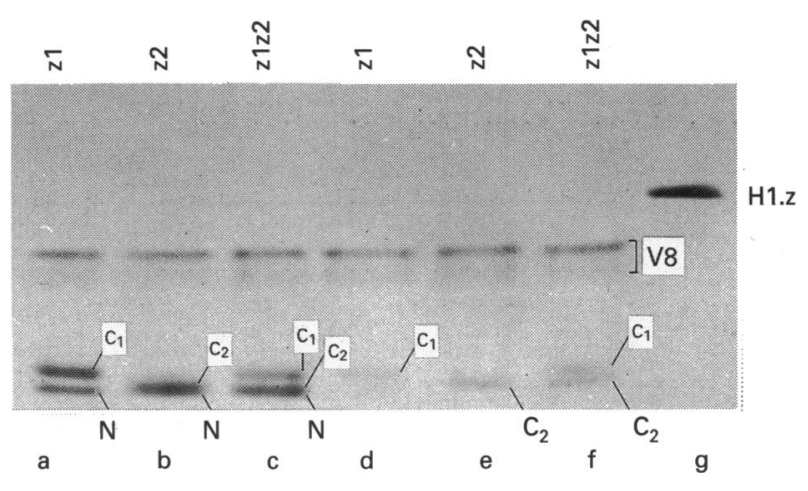

Figure 4 Partial digestion by Staphylococcus aureus V8 protease of the three duck erythrocyte polymorphic forms of H1.z (z1, z2 and z1z2) before (lanes a-c) and after (lanes $d-f$ ) chemical cleavage with NBS

Lane $\mathrm{g}$, undigested histone $\mathrm{H1.z}$; V8, Staphylococcus aureus V8 protease; $\mathrm{C}_{1}$, V8 protease Cterminal fragment of subfraction $\mathrm{H1.21} ; \mathrm{C}_{2}, \mathrm{~V} 8$ protease $\mathrm{C}$-terminal fragment of subfraction $\mathrm{H} 1.22$; N, V8-protease $\mathrm{N}$-terminal fragment of the $\mathrm{H} 1.2$ fraction from both homozygotic and heterozygotic birds.

peptide, $\mathrm{C}_{1}$, with a greater apparent molecular mass than peptide $\mathrm{C}_{2}$ arising from H1.z2. In the case of histone H1.z from heterozygotic birds (z1z2), both $\mathrm{C}_{1}$ and $\mathrm{C}_{2}$ were produced, while $\mathrm{N}$-terminal peptides (designated with a letter $\mathrm{N}$ in Figure 3) were identical regardless of the H1.z phenotype. Thus the putative differences in amino acid sequence between subtypes $\mathrm{zl}$ and $\mathrm{z} 2$ occur in the region between amino acid residue 106 and the $\mathrm{C}$ terminus.

The third enzyme employed for hydrolysing histone H1.z was protease V8 from Staphylococcus aureus, which cleaves peptide bonds at the C-terminal side of aspartic and glutamic acid residues (Cleveland et al., 1977). Although there is an Asp residue in duck $\mathrm{H} 1$ at position 72 , it seems (Croft, 1980) that the aspartyl-peptide bond is not cleaved under our experimental conditions. After treating histone H1.z with protease V8, two peptides were obtained (Figure 4). These either differed in molecular mass, as in the case of H1.z1 (lane a) or were almost identical, as in the case of H1.z2, and co-migrated as a heavily stained band (lane b). These results indicate that protease V8 preferentially hydrolyses one out of six glutamic acid residues in duck erythrocyte $\mathrm{H1}$. Glutamic acid residues 53, 74 and 116 are bound with arginine or lysine, rendering the relevant peptide bonds resistant to cleavage by this enzyme (Böhm et al., 1988). $\mathrm{Glu}^{42}$ is linked to a hydrophobic amino acid (Leu) that may diminish the rate of cleavage (Drapeau et al., 1972). Moreover, the rate of proteolysis of a Glu-Leu bond appears to depend on primary and secondary structure variations in adjoining regions of $\mathrm{H} 1$ (Böhm et al., 1988). Thus in our experiment the cleavage of H1.z preferentially took place in the middle of $\mathrm{H} 1 . \mathrm{Z}$ at Glu ${ }^{113}$, which is bound to threonine. We believe that limited proteolysis of $\mathrm{H} 1 . z 1$ with protease V8 created two peptides: an N-terminal peptide spanning from the N-terminus of $\mathrm{H} 1 . z 1$ to the $\mathrm{Glu}^{113}$ residue, and a $C$-terminal peptide (in this case $C_{1}$ peptide) that encompasses the part of the molecule from amino acid residue 114 to the $\mathrm{C}$-terminus. The products of the proteolytic digestion of $\mathrm{H} 1 . \mathrm{z} 2$ (N peptide and $\mathrm{C}_{2}$ peptide) migrated in the gel as a broad band (Figure 4, lane b). When H1.z from birds with the phenotype $\mathrm{z} 1 \mathrm{z} 2$ was treated with protease $\mathrm{V} 8$ and the products were resolved in the gel a weak band, containing peptide $C_{1}$ arising from $\mathrm{H} 1 . \mathrm{zl}$, and a broad band, containing both peptide 
$\underline{\mathbf{N}}$

$\mathrm{Tyr}^{71} \mathrm{Phe}^{105} \mathrm{Glu}^{113}$

$\mathrm{C}_{\mathrm{z} 1}$

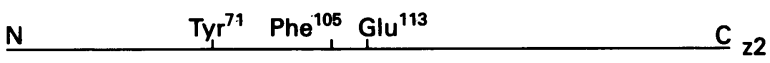

Higure 5 Schematic representation of the cleavage patterns of allelic forms of histone H1.2 by NBS at Tyr ${ }^{71}, \alpha$-chymotrypsin at Phe ${ }^{105}$ and protease V8 at Glu ${ }^{113}$

We have assumed that the distribution of these amino acids in our $\mathrm{H} 1.2$ is identical to that reported previously for duck $\mathrm{H} 1$ (Tönjes and Doenecke, 1987). The digestion patterns of H1.Z presented in Figures 2-4 seems to indicate that allelic forms of histone $\mathrm{H1} . \mathrm{z}$ differ slightly with regard to the lengths of their C-terminal peptides.

$\mathrm{C}_{2}$ originating from $\mathrm{H} 1 . \mathrm{z} 2$ as well as $\mathrm{N}$-terminal peptides from H1.z1 and H1.z2, were apparent (Figure 4, lane c).

To confirm the preferential cleavage of $\mathrm{H1.z}$ at $\mathrm{Glu}^{113}$ by protease V8 under our experimental conditions, and to demonstrate that the band designated ' $N$ ' in Figure 4 (lanes a-c) represented an N-terminal peptide of $\mathrm{H} 1 . z 1$ and/or $\mathrm{Hl} . \mathrm{z} 2$, three phenotypic forms of histone H1.z were cleaved first with NBS and then with protease V8 (Figure 4, lanes d-f). After staining with Coomassie Blue the $\mathrm{N}$-terminal peptide was no longer visible in the gel pattern of histone $\mathrm{H} 1 . z 1$, i.e. only one peptide was revealed (peptide $C_{1}$; Figure 4, lane d). Similarly, in the case of H1.z2, the part of the band containing the N-peptide disappeared, leaving only the peptide $\mathrm{C}_{2}$ (Figure 4, lane e). After cleavage of histone H1.z from heterozygotic birds (z1z2) with both agents, the intensity of staining of the two resulting polypeptides $\left(C_{1}\right.$ and $\left.C_{2}\right)$ was comparable (Figure 4, lane $f$ ).

The results of the cleavage of the allelic forms of histone $\mathrm{H} 1 . \mathrm{z}$ with chemical and enzymic agents are briefly summarized in Figure 5. On the basis of the data presented in Figure 4 (lane b), it was assumed that the V8-protease-susceptible $\mathrm{Glu}^{113}$ residue was located close to the middle of the H1.z2 molecule. Because the apparent molecular mass of the allelic form H1.zl was greater by about $1 \mathrm{kDa}$ than that of $\mathrm{H} 1 . \mathrm{z2}$ (Figure 2b), it was likely that subtype $\mathrm{zl}$ might be longer by a few amino acid residues. It is possible that the longer allelic form, H1.z1, might have originated by a duplication of a short peptide stretch within the C-terminal part of the duck H1.z molecule. A variable number of repetitions of a short peptide were found among the polymorphic forms of lysine-rich histone $\mathrm{H} 5$ in Acanthis flammea
(Gorel et al., 1982) and of histone H2B from the sperm cells of the sea urchin (von Holt et al., 1984). The location of the variable region of allelic subtypes of duck H1.z in the C-terminal domain is in agreement with findings that $\mathrm{C}$-terminal parts of $\mathrm{H} 1$ histones are not conserved in sequence either between different species (Wells and Brown, 1991) or between distinct non-allelic subtypes within a species (Shannon and Wells, 1987).

We thank Professor Adam Mazanowski and Dr. Juliusz Ksiażkiewicz, Poultry Research and Development Center, Branch of Waterfowl Breeding, Dworzyska, Poznań, Poland, for kindly allowing us to use their duck stocks.

\section{REFERENCES}

Berdnikov, V. A. and Gorel, F. L. (1975) Mol. Biol. (Moscow) 9, 699-705

Berdnikov, V. A., Gorel, F. L., Argutinskaya, S. V., Cherepanov, V. A. and Kilyeva, E. V. (1976) Mol. Biol. (Moscow) 10, 887-896

Böhm, L., Sautiere, P., Cary, P. D. and Meader, D. L. (1988) Biochim. Biophys. Acta 956, 224-231

Bradbury, E. M., Chapman, G. E., Danby, S. E., Hartman, P. G. and Riches, P. L. (1975)

Eur. J. Biochem. 57, 521-528

Bustin, M. and Cole, R. D. (1969) J. Biol. Chem. 244, 5291-5294

Cleveland, D. W., Fischer, S. G., Kirschner, M. W. and Laemmli, U. K. (1977) J. Biol. Chem. 252, 1102-1106

Croft, L. R. (1980) Introduction to Protein Sequence Analysis, Wiley, New York

Croston, G. E., Kerrigan, L. A., Lira, L. M., Marshak, D. R. and Kadonaga, J. T. (1991) Science 251, 643-649

Drapeau, G. R., Bailey, Y. and Houmard, J. (1972) J. Biol. Chem. 247, 6720-6726

Gorel, F. L., Bernikov, V. A. and Rozov, S. M. (1982) Mol. Biol. (Moscow) 16, 790-798

Harris, H. (1980) The Principles of Human Biochemical Genetics, Elsevier, Amsterdam

Hoyer-Fender, S. and Grossbach, U. (1988) Eur. J. Biochem. 176, 139-152

Kostyleva, E. I., Selivanova, G. V. and Zalenskaya, I. A. (1989) Mol. Biol. (Moscow) 23, 73-79

Laemmli, U. K. (1970) Nature (London) 227, 680-685

Laybourn, P. J. and Kadonaga, J. T. (1991) Science 254, 238-244

Lin, R., Cook, R. G. and Allis, C. D. (1991) Genes Dev. 5, 1601-1610

Maeder, D. L. and Böhm, L. (1991) Biochim. Biophys. Acta 1076, 233-238

Pałyga, J. (1990a) Biochem. Genet. 28, 359-365

Pałyga, J. (1990b) Int. J. Biochem. 22, 1351-1361

Pałyga, J. (1991a) Biochem. Genet. 29, 431-445

Pałyga, J. (1991b) Hereditas 114, 85-89

Pałyga, J. (1991c) Int. J. Biochem. 23, 845-849

Ramachandran, L. K. and Witkop, B. (1967) Methods Enzymol. 11, 283-299

Roth, S. Y. and Allis, C. D. (1992) Trends Biochem. Sci. 17, 93-98

Sambrook, J., Fritsch, E. F. and Maniatis, T. (1989) Molecular Cloning: A Laboratory

Manual, 2nd edn., Cold Spring Harbor Laboratory Press, Cold Spring Harbor, NY

Shannon, M. F. and Wells, J. R. E. (1987) J. Biol. Chem. 262, 9664-9668

Thomas, J. 0. (1984) J. Cell. Sci. Suppl. 1, 1-20

Tönjes, R. and Doenecke, D. (1987) J. Mol. Evol. 25, 361-370

von Holt, C., de Groot, P., Schwager, S. and Branti, W. F. (1984) in Histone Genes:

Structure, Organization and Regulation (Stein, G. S., Stein, J. L. and Marzluff, W. F., eds.), pp. 65-105, Wiley, New York

Wells, D. and Brown, D. (1991) Nucleic Acids Res. 19, Suppl. 2173-2188 